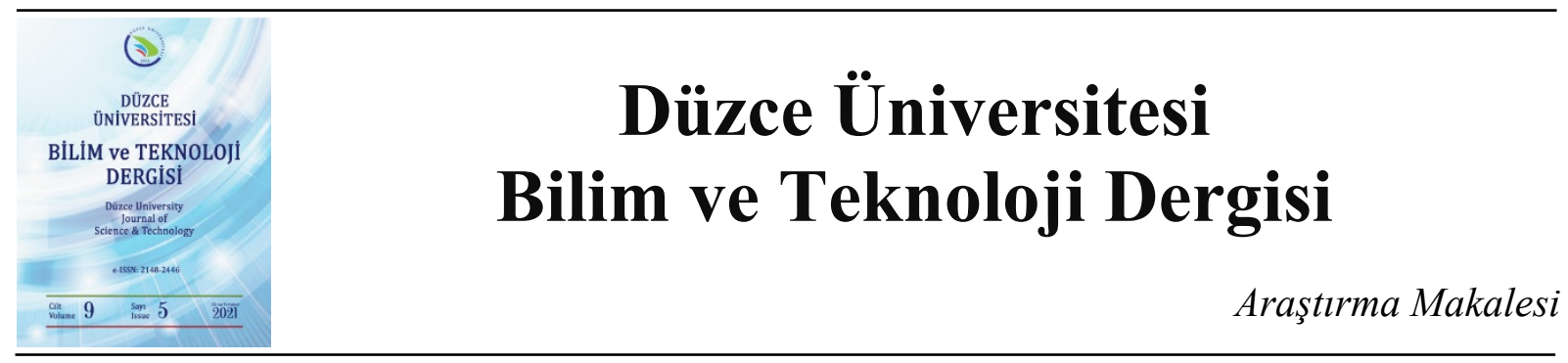

\title{
Kuru Yatakta Oluşan Baraj Yıkılmasının Sayısal Modellemesi
}

\author{
(D) Oğuz ŞiMŞEK ${ }^{\mathrm{a}, *}$, (D) Hüseyin İ̧SLEK ${ }^{\mathrm{a}}$, (iD) Veysel GÜMÜŞ ${ }^{\mathrm{a}}$ \\ a İşaat Mühendisliği Bölümü, Mühendislik Fakültesi, Harran Üniversitesi, Şanlıurfa, TÜRKIYYE \\ * Sorumlu yazarın e-posta adresi: oguzsimsek@harran.edu.tr
}

DOI: 10.29130/dubited.897718

\begin{abstract}
Öz
Baraj yıkılmasının meydana gelmesi durumunda özellikle barajın mansap bölgesinde oluşacak mal ve can kaybının en aza indirgenmesi ve barajın planlama aşamasında gerekli önlemlerin alınması için, baraj yıkılmasının sayısal modelleme teknikleriyle analiz edilmesi önemlidir. Ayrıca, mevcut barajların yayılım dalgasının mansap bölgesine olan etkisinin farklı senaryolarla analizi de bu yöntemler kullanılarak gerçekleştirilebilmektedir. Bu çalışmada, baraj mansabında herhangi bir yapı veya akım bulunmaması durumunda (kuru yatak) gerçekleşen baraj yıkılmasının sayısal modellemesi, sonlu hacimler yöntemiyle ANSYS- Fluent paket programı kullanılarak yapılmıştır. Sayısal modellemelerde baraj yıkılması yayılım dalgası akımını idare eden temel denklemlerin

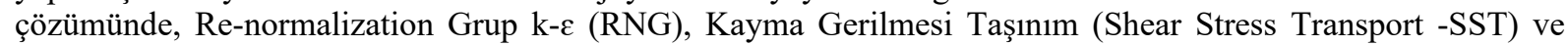
Ayrılmış Girdap Benzetim (Detached Eddy Simulation- DES) modelleri, su hava ara kesitinin belirlenmesinde ise akışkan hacimleri yöntemi (Volume of Fluid-VOF) kullanılmıştır. Farklı zamanlarda elde edilen deneysel ve sayısal su yüzü profillerinin karşılaştırılmasından, DES modelinin kullanılan diğer modellere kıyasla nispeten daha başarılı olduğu belirlenmiştir. Çalışma sonucunda, baraj yıkılması durumunda barajların mansap bölgesinin güvenlik önlemlerinin ve risk sınırlarının belirlenmesinde, sayısal modellemelerin güvenle kullanılabileceği görülmüştür.
\end{abstract}

Anahtar Kelimeler: Baraj yıkılması, Sayısal modelleme, Akışkan hacimleri yöntemi, Ayrılmış girdap modeli

\section{Numerical Modeling of Dam Break on Dry Bed}

\begin{abstract}
In case of a dam break, it is important to analyze the break of the dam with numerical modeling techniques to minimize the loss of property and life in the downstream region of the dam and to take the necessary precautions during the planning of the dam. In addition, the impact of the propagation wave of existing dams on the downstream region with different scenarios can be analyzed using these methods. In this study, the numerical modeling of the dam break in the absence of any structure or flow (dry bed) on downstream of the dam is made with the ANSYS-Fluent package program using the finite volume method. In numerical modeling, Renormalization Group k- $\varepsilon$ (RNG), Shear Stress Transport (SST) and Detached Eddy Simulation (DES) models are used to solve the basic equations governing the dam break propagation wave flow. Volume of Fluid method (VOF) is used to determine of the water-air cross-section. Comparing the experimental and numerical water surface profiles obtained at different times, it was determined that the DES model is relatively more successful than the other models used. As a result of the study, it is seen that numerical models can be used safely in determining the safety measures and risk limits of the downstream region in case of a dam break.
\end{abstract}

Keywords: Dam-break, Numerical model, Volume of fluid, Detached eddy simulation 


\section{GIRIS}

Barajlar, sulama ve içme suyu temini, taşkın kontrolü ve daha birçok amaç için inşa edilen hidrolik yapılardır. Barajların rezervuarlarında depolanan ve taşkın anında gelen sudan dolayı, baraj gövdesinin toptan veya kısmen göçmesi durumunda, baraj mansap bölgesinde bulunan canlılar ve yerleşim yerleri risk altında bulunmaktadır. Baraj yıkılması durumunda, can ve mal kaybının azaltılması ve gerekli tedbirlerin alınması açısından baraj yıkılması durumunda oluşan yayılım dalgasının mansap bölgesinde etkileyeceği bölgeler, barajların planlama aşamasında belirlenmelidir. Etkilenecek bölgenin, baraj yıkılmasından önce belirlenmesi için deneysel çalışmalar gerçekleştirilse de bu verilerin gerçek senaryosu tamamen gerçekleştirilememektedir. Son yıllarda, bu deneysel çalışmaların yanında bilgisayar teknolojisinin gelişmesiyle birlikte hesaplamalı akışkanlar dinamiği yöntemlerinin kullanıldığı sayısal modelleme yazılımları, farklı yapı akım etkileşimi problemlerinin çözümünde oldukça sık tercih edilmeye başlanmıştır [1-6]. Bu çalışmalar incelendiğinde genel olarak sayısal model sonuçlarının deneysel verilerle doğrulanması neticesinde, sayısal modellemelerin oldukça başarılı olduğu ve deneysel verilere tatmin edici seviyede yakın tahminde bulunduğu belirlenmiştir. Shigematsu ve ark. [7], farklı başlangıç şartlarında baraj yıkılması dalgasını k- $\varepsilon$ türbülans modelini kullanarak sayısal olarak modellemişlerdir. Sayısal model sonucunda elde edilen su yüzü profillerini, deneysel su yüzü profilleriyle karşılaştırmışlardır. Karşılaştırma sonucunda, deneysel ve sayısal su yüzü profillerinin birbiriyle oldukça uyumlu olduğunu belirtmişler ve baraj yıkılması durumunda oluşan türbülansın dağılımı değerlendirilmiştir. Kocaman [8], baraj yıkılması problemini deneysel, teorik ve sayısal olarak analiz etmiştir. Baraj yıkılması dalgasının su yüzü profili kuru yatak, farklı mansap-memba su yükseklikleri oranlarında $(\alpha=0,1,0,2$ ve 0,4$)$ ve mansap bölgesinde farklı yapıların bulunması durumunda irdelenmiştir. Farklı yapı ve akım koşullarında elde edilen deneysel çalışma sonuçları sayısal model sonuçlarıyla karşılaştırılmıştır. Sayısal model sonuçlarının deneysel verilerle uyumlu olduğu vurgulanmıştır. Khoshkonesh ve ark. [9], farklı başlangıç (kuru-1slak) ve geometrik koşulların baraj yıkılma akışı üzerindeki etkisini araştırmışlardır. Serbest yüzeyin gelişimi, akışkan hacimleri yöntemi kullanılarak belirlenmiştir. Ağ çözünürlüğü ve türbülans kapatma modellerine duyarlılıklar, üç hücre boyutunda ve dört modelde değerlendirilmiştir. Sayısal modellemelerde, Reynolds Ortalamalı NavierStokes (RANS) ve Büyük Girdap Benzetimi (Large Eddy Simulasyon-LES) kullanılmış ve elde edilen sonuçlar literatürde bulunan deneysel verilerle karşılaştırılmıştır. LES'in serbest yüzeyini belirlemede, diğer türbülans modellerinden nispeten daha iyi olduğu belirlenmiştir. Çalışma sonucunda, başlangıç ve geometrik koşulların serbest yüzeyin ilerlemesi, akış enerjisi, dışarı ve içeri akış hidrografları ve sonuçta ortaya çıkan kuvvetler üzerinde önemli olduğu ifade edilmiş̧ir. Munoz ve Constantinescu [10], baraj yıkılma dalgasını üç boyutlu sayısal olarak modellemek için akışkan hacimleri yöntemini kullanmışlardır. Sayısal modellemelerde akımın hareketini idare eden temel denklemlerin çözümünde, RANS tabanlı türbülans modelini kullanmışlardır. Laboratuvarda gerçekleştirilen deneysel çalışmaların sonuçlarının, üç boyutlu sayısal model sonuçları arasında iyi bir uyum olduğu gözlemlenmiştir. Liu ve ark. [11], eğimli bir yatak boyunca hareket eden baraj yıkılma dalgalarının özelliklerini araştırmışlar ve sel uyarısının zamanında verilerek risk azaltılmasına yardımcı olabileceğini öngörmüşlerdir. Laboratuvar çalışmaları memba su derinliğinin, yatak eğiminin ve kuyruk suyu derinliğinin oldukça geniş aralıkta değiştiği akım koşullarında gerçekleştirilmiştir. Kuyruk suyu derinliği, ortalama hız ve dalga hızını hesaplamak için farklı akım durumlarında su seviyeleri ölçülmüştür. Sonuç olarak, mansap kısmının kuru yatak olması durumunda yatak eğiminin artmasının, ters dalga şiddetini azaltırken, düz dalga şiddetinin önemli ölçüde arttıracağı belirlenmiştir. Ayrıca, $\alpha \geq 0,3$ olduğu durumda, akım bir süre geliştikten sonra rezervuar alanına doğru yayılan ekstra negatif dalgalar oluştuğu, $\alpha \geq 0,6$ olduğu durumda ise mansaba doğru yayılan Favre dalgalarının oluştuğunu belirtilmiştir. Su seviyesinin ve ortalama hızın, ekstra negatif dalgaların ve Favre dalgalarının etkisine bağlı olarak dalgalandığını, bu tür dalgalanma frekansı, su derinlik oranının artmasıyla arttığını, ilk ekstra negatif dalganın ve ilk mansap akım dalga hızı için deneysel formüller elde etmişlerdir. Bunun yanında, deneysel sonuçlar bazı analitik çözümlerle de karşılaştırılmış ve karşılaştırma sonucundan bu analitik çözümlerin geliştirilmesi sırasında yapılan varsayımların geçerliliği ve kısıtlılıkları deneysel ölçümlerle tartışılmıştır. Ye ve ark. [12], mansap kısmının kuru yatak, sslak yatak ve önünde engeller olması gibi farklı yatak durumlarında baraj yıkılma dalgasının yayılımını modellemek için serbest ağ (mesh free) yöntemini kullanmışlardır. $\mathrm{Bu}$ yöntemin sonuçları, mevcut deneysel ölçümlerle karşılaştırılarak doğrulanmıştır. Doğrulanmış bu 
sayısal yöntem daha sonra, farklı mansap koşullarında yayılan baraj yıkılma dalgasını modellemek için kullanılmıştır. Modellemelerde serbest yüzey profili, akış deseni, ön dalga hareketi ve yatak kayma gerilmesi gibi akış özellikleri irdelenmiştir. Kocaman ve ark. [13], baraj yıkılması durumunda mansap bölgesinde daralmanın olduğu karmaşık akım problemini deneysel ve sayısal olarak modellemişlerdir. Mansap bölgesinde üç farklı yanal daralma geometrisi için dikdörtgen kesitli ve yatay kanalda, kuru yatak durumunda incelemişlerdir. Deneysel sonuçlar, akışkan hacimleri yöntemiyle Sığ Su Denklemleri ve RANS denklemlerinin k- $\varepsilon$ tabanlı sayısal çözümü ile karşılaştırmışlardır. Hesaplanan ve ölçülen sonuçlar arasında iyi benzerlik elde edilmiş ve RANS modellemesinin, diğer modellere kıyasla deneysel sonuçlarla daha iyi bir uyum gösterdiğini belirlemişlerdir. Çalışma sonucunda, sunulan yeni deneysel verilerin, düzensiz topografya üzerindeki baraj kırılma akışlarının simülasyonu için sayısal modellerin doğrulanması için kullanılabileceği sonucuna varılmıştır. Peng ve ark. [14], bir baraj yıkılması sonucu oluşan selin gelişimini ve bir yapı üzerindeki çarpma basıncını sayısal modelle ele almışlardır. Sayısal modeli doğrulamak için ilk olarak bir laboratuvar ortamında deneysel çalışmalar gerçekleştirmişlerdir. Yapıya yakın akış rejimini, yapı üzerindeki çarpma basıncının zamansal değişimleri ve dağılımlarını incelemişlerdir. Bunun yanında, ilk rezervuar su derinliğinin maksimum basınçlar üzerindeki etkilerini tartışmışlardır. Yapının memba ve mansap en kesitindeki su yüzeyi profillerinin tamamen farklı olduğunu ve yüzey hızı dağılımları önemli ölçüde farklıların bulunduğu belirlenmiştir. Taşkın suyu yapıya ilk temas ettiğinde, yapının büyük bir anlık çarpma basıncına maruz kaldığı ve bu basıncın değerinin ilk darbeden sonraki maksimum basıncın 1,5-3,0 katına ulaşabileceği ve anlık çarpma basıncının, ilk rezervuar su derinliği ile orantılı olduğunu tespit etmişlerdir. Ayrıca, yapının ön tarafında duvara etkiyen maksimum basıncının dağılımı hem yatay hem de düşey yönlerde doğrusal olmadığını belirlemişlerdir. Literatürde bulunan çalışmalar incelendiğinde, baraj yıkılma probleminin hidrodinamik yöntemlere dayalı analizinin oldukça kısıtlı olduğu belirlenmiştir. Baraj yıkılması yayılım dalgasının hareketini idare eden temel denklemlerin çözümünün akıma ait farklı parametrelerin belirlenmesini esas alan türbülans modellerinin başarısının karşılaştırılması konusunda eksikliklerin bulunduğu dikkat çekmektedir.

Bu çalışmada, Kocaman [8] tarafından laboratuvar ortamında kuru yatak üzerinde deneysel olarak incelenen baraj yıkılması probleminin sayısal modellemesi yapılmıştır. Farklı zamanlarda deneysel olarak elde edilen baraj yıkılması dalgasının profili, sayısal model sonuçlarıyla karşılaştırılmıştır. Kocaman [8] tarafindan kullanılmayan Re normalization Grup k- $\varepsilon$ (RNG), Kayma Gerilmesi Taşınım (Shear Stress Transport-SST) ve Ayrılmış Girdap Benzetim (Detached Eddy Simülasyonu-DES) türbülans modelleriyle elde edilen sayısal model sonuçlarının deneysel sonuçlarla karşılaştırılması sonucunda, deneysel verilere en yakın tahminde bulunan türbülans modeli belirlenmiştir. Ayrıca, deneysel olarak değerlendirilmeyen basınç, hız vektörü ve türbülans kinetik enerji desenleri sayısal model sonuçlarından elde edilerek değerlendirilmiştir.

\section{DENEYSEL CALIȘMA}

Deneyler, Kocaman [8] tarafından Çukurova Üniversitesi Hidrolik laboratuvarında bulunan dikdörtgen en kesitli açık kanalda yapılmıştır (Şekil 1). Deneylerin gerçekleştirildiği açık kanalın tüm yüzeyleri camdan imal edilmiş ve uzunluğu, yüksekliği ve genişliği sırasıyla $9 \mathrm{~m}, 0,34 \mathrm{~m}$ ve $0,3 \mathrm{~m}$ 'dir. Baraj yıkılmasının deneysel olarak modellenmesinde açı kanala herhangi bir eğim verilmemiş olup yatay taban üzerinde gerçekleştirilmiştir. Baraj yıkılma dalgası profilinin deneysel olarak elde edilmesinde yüksek çözünürlüklü kameralar kullanılmış olup, görüntü işleme teknikleriyle görüntü kalitesi arttırılmış ve kalibrasyonu yapılmıştır (Şekil 2).

Baraj gövdesinin deneysel olarak temsil edilmesinde kayar kapak kullanılmış olup, bu kayar kapak kanal girişinden $465 \mathrm{~cm}$ uzaklığa yerleştirilmiştir. Kayar kapağın ani olarak hareketini sağlamak üzere makara sistemiyle $15 \mathrm{~kg}$ ağırlık $150 \mathrm{~cm}$ yükseklikten serbest bırakılmıştır (Şekil 1). Baraj yıkılmasının ani olarak değerlendirilmesi için, kapağın kaldırılma zamanının, Lauber ve Hager [15] tarafından önerilen 1,25 $\left(\mathrm{h}_{0} / \mathrm{g}\right)^{1 / 2}\left(\mathrm{~h}_{\mathrm{o}}\right.$ memba su yüksekliği, g yer çekimi ivmesi) değerinden küçük olması gerekmektedir. Kapak açılma zamanının video kayıtlarından incelenmesinden, bu sürenin 0,06-0,08 s. olduğu ve formülle 
hesaplanan 0,2 s. değerinden küçük olduğu görülmüştür. Baraj yıkılması dalgasının video kayıtlarında daha fark edilmesi ve net görünmesi için su içerisine gıda boyası ilave edilmiştir. Kapak kaldırılmadan önce baraj rezervuarını temsil eden bölgede (kapak membası) su ile doldurulmuş ve akım tam durgun hale geldikten sonra ölçümlere başlanmıştır. Kayar kapak membasındaki su derinliği $\left(h_{0}\right) 25 \mathrm{~cm}$ olarak ayarlanmıştır.

Deneysel olarak baraj yıkılma dalgasının yayılım zamanı $(\mathrm{t})\left(\mathrm{g} / \mathrm{h}_{0}\right)^{1 / 2}$ ifadesi ile çarpılarak ve yükseklikler ise memba su derinliği $\mathrm{h}_{0}$ ile bölünerek boyutsuz hale getirilmiştir. Bu şekilde boyutsuz hale getirilen zaman ifadesi " $\mathrm{T}$ " ile temsil edilmiştir. $\mathrm{T}=0,0,63,2,51,5,01$ ve 7,52 olduğu durumlarda elde edilen deneysel su yüzü profilleri incelenmiştir. Mansap bölgesinde farklı su yüksekliklerinde deneysel ölçümler gerçekleştirilmiştir. Bu çalışmada mansap bölgesinde herhangi bir su bulunmadığ1 (kuru yatak) durumda yapılan ölçümlerin sayısal modellemesi yapılmıştır.

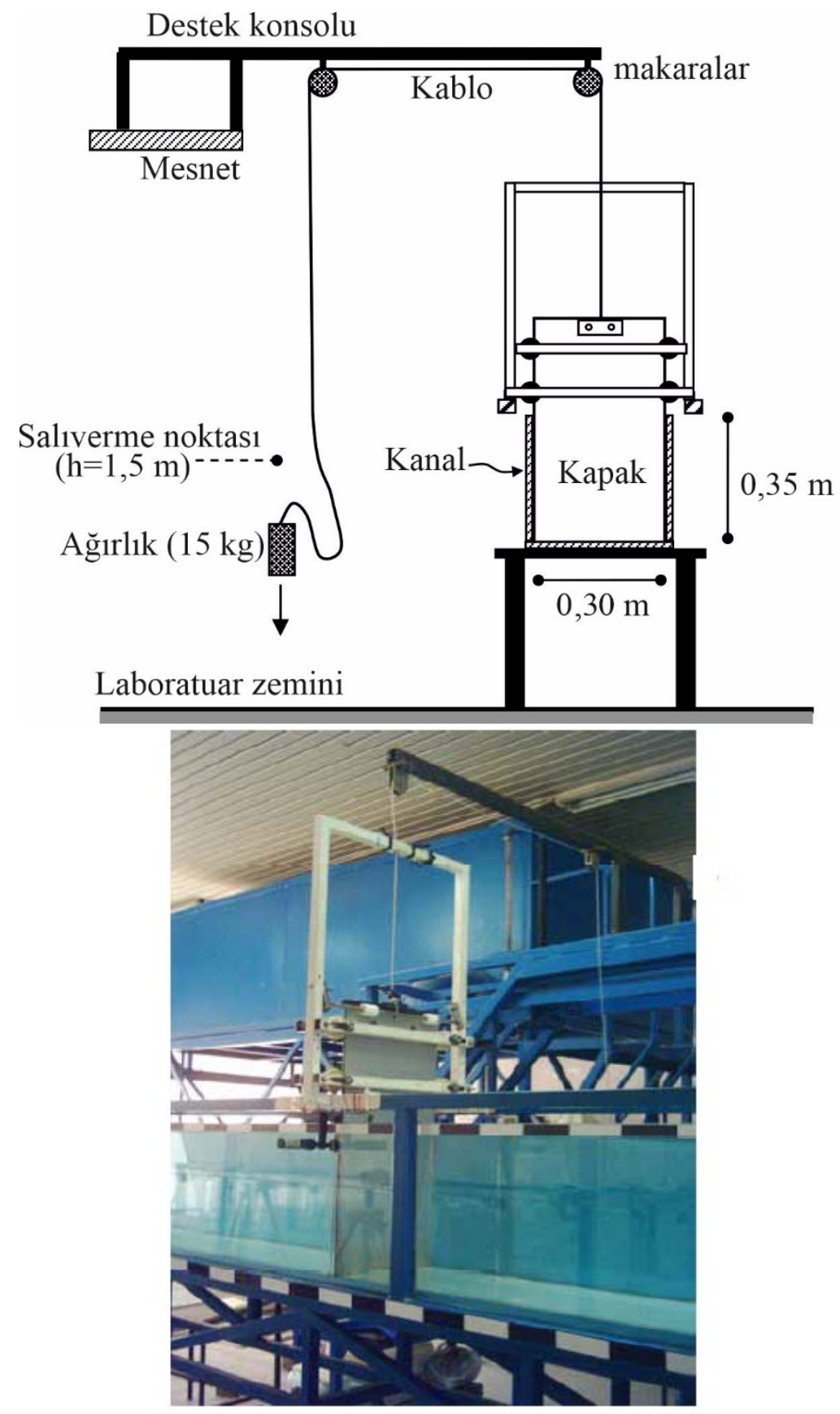

Şekil 1. Deney düzeneği ve şematik görüntüsü [8]. 


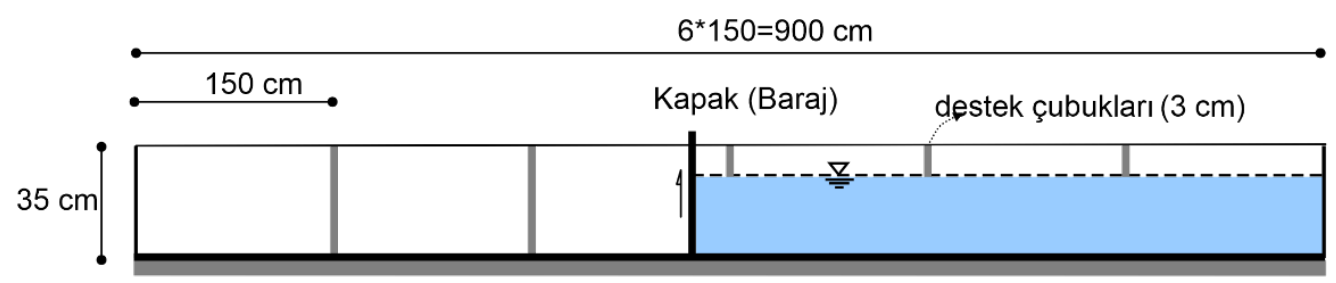

(A-A Kesiti)

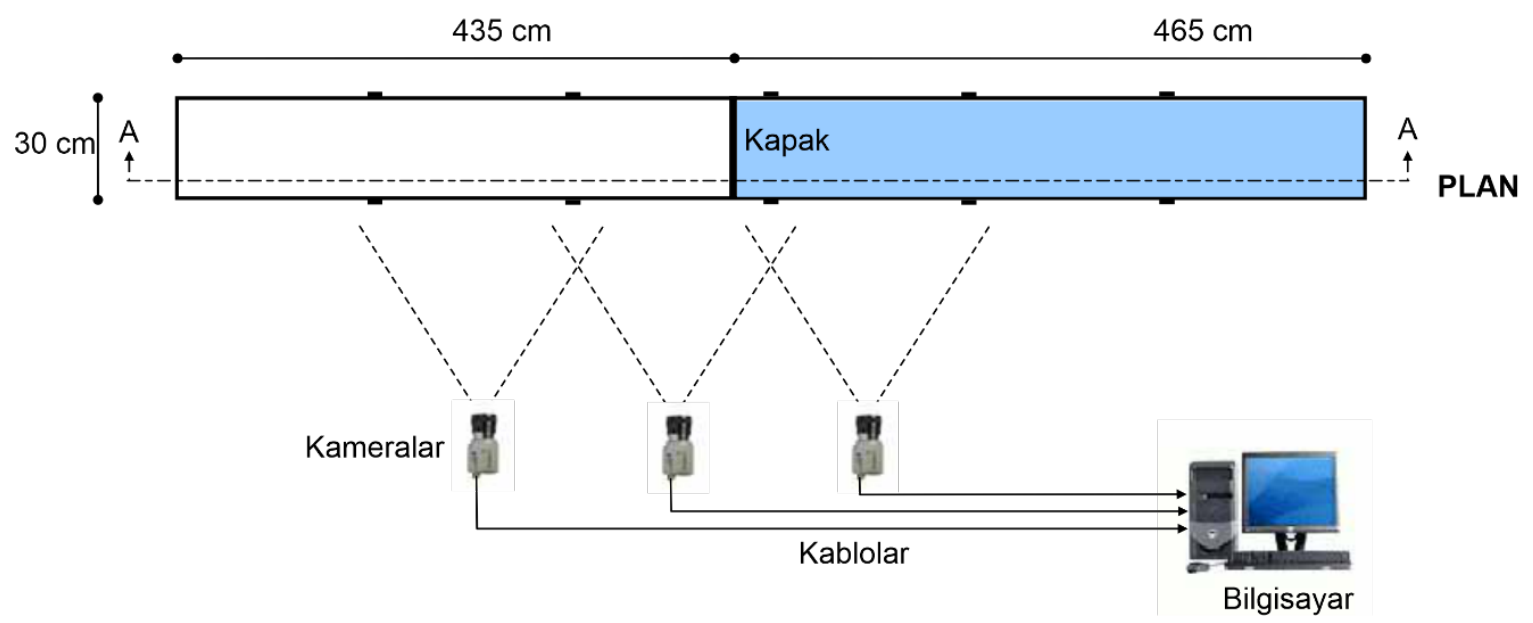

Şekil 2. Ölçüm sistemi şematik görüntüsü [8].

\section{SAYISAL MODELLEME}

Baraj yıkılması probleminde oluşan yayılım dalgası, iki boyutlu, sıkışmayan, türbülanslı bir akım türüdür. Baraj yıkılması dalgasının hareketini idare eden süreklilik eşitliği Denklem 1'de, momentum eşitliği ise Denklem 2'de verilmiştir.

$\frac{\partial u_{i}}{\partial x_{i}}=0$

$\rho\left(\frac{\partial u_{i}}{\partial t}+u_{j} \frac{\partial u_{i}}{\partial x_{j}}\right)=\rho g_{i}-\frac{\partial p}{\partial x_{i}}+\mu \frac{\partial^{2} u_{i}}{\partial x_{j}^{2}}+\frac{\partial}{\partial x_{j}}\left(\tau_{\mathrm{ij}}\right)$

$\mathrm{Bu}$ denklemlerde bulunan, $u_{i}$ ortalama hız bileşenlerini, $p$ ortalama basıncı, $\mu$ akışkanın dinamik viskozitesini, $\rho$ akışkanın yoğunluğunu, $\rho g_{i}$ yerçekiminin sebep olduğu kütlesel kuvveti, $t$ zamanı, $\tau_{i j}$ ise türbülans (Reynolds) gerilmelerini ifade etmektedir. Reynolds gerilmeleri, Boussinesq yaklaşımına göre Denklem 3'teki gibi ifade edilir:

$\tau_{\mathrm{ij}}=-\rho \overline{u_{i}^{\prime} u_{j}^{\prime}}=\mu_{t}\left(\frac{\partial u_{i}}{\partial x_{j}}+\frac{\partial u_{j}}{\partial x_{i}}\right)-\frac{2}{3} \delta_{\mathrm{ij}} \rho k$

Burada, $u_{i}^{\prime}$ ve $u_{j}^{\prime}$ türbülans hız sapınçları ve $\mu_{\mathrm{t}}$ türbülans viskozitesi olup $\delta_{i j}$ Kronecker deltadır $(\mathrm{i}=\mathrm{j}$ için $\left.\delta_{i j}=1\right)$.

Yukarıdaki denklemler içerisinde, üç boyutlu akışta bir basınç, üç hız, altı türbülans kayma gerilmesi bileşeni olmak üzere toplam 10 adet bilinmeyen olarak bulunmaktadır. Akışın iki boyutlu olması durumunda ise bir adet hız bileşeni ve 3 adet türbülans gerilmesi bileşeni azalmakta ve bilinmeyen sayısı 
6 olmaktadır. 6 adet bilinmeyene karşılık, bu bilinmeyenlerin çözümü için 3 adet denklem bulunmasından dolayı bu bilinmeyenlerin çözümü eldeki denklemler kullanılarak mümkün olmamaktadır. Denklem içindeki bilinmeyenlerin çözümünün gerçekleşmesi için Denklem 3'teki türbülans viskozitesinin çözülmesi için türbülans kapatma modelleri kullanılmaktadır. Kocaman [8] tarafindan sayısal modellemede sadece Standart $k-\varepsilon$ (SKE) türbülans modeli kullanılmıştır. $\mathrm{Bu}$ çalışmada, $\mu_{t}$ türbülans viskozitesinin modellenmesi için Yakhot ve ark. [16-17] tarafından geliştirilen, türbülans kinetik enerji $(k)$ ve kinetik enerji kayıp oranı $(\varepsilon)$ denklemlerini çözen Re normalization Grup k- $\varepsilon$ (RNG) türbülans kapatma modeli, Menter [18] tarafından k ve türbülans kinetik enerji özgül kayıp oranı $(\infty)$ denklemlerini çözen Kayma Gerilmesi Taşınım (Shear Stress Transport-SST) modeli ve katı sınır üzerinde sınır tabakasında kararsız RANS tabanlı çözüm yaparken, ayrılmış bölgelerde LES'i kullanan Ayrılmış Girdap Modeli (Detached Eddy Simülasyonu-DES) kullanılmıştır [19]. Kullanılan türbülans kapatma modellerinden, RNG akımda meydana gelen ayrılmaların ve eğriselliğin bulunması durumunda standart k- $\varepsilon$ modeline kıyasla başarılı olduğu geliştirenler tarafından iddia edilmiştir. SST modeli ise türbülans viskozitesinin hesabında sınır tabaka içerisinde orijinal $\mathrm{k}-\omega$ modelini, serbest kayma akışlarında ise standart $k-\varepsilon$ modelini kullanmasından dolayı hibrit bir modeldir. Her iki modelin üstünlüklerinin bir arada kullanılmasını sağlamasından dolayı SST modeli, akımda ayrılmaların ve ikincil akımların söz konusu olduğu ve hız değerlerinin oldukça hızlı değiştiği akım durumlarında başarılı olduğu belirtilmiştir. DES modelinde ise hesaplama maliyetleri, LES hesaplama maliyetlerinden daha az, ancak RANS'tan daha yüksektir. Her iki modelin bir arada bulundurulmasından dolayı bu DES modeli de hibrit bir model olarak adlandırılmaktadır. Ayrıca, DES modelinin karmaşık akım problemlerinin çözümünde oldukça başarılı sonuçlar verdiği ve LES kadar küçük ağ elemanlarından oluşan hesaplama ağına ihtiyaç duymadığı belirtilmektedir [20].

Sayısal modellemelerde iterasyon adımı büyüklügü, Courant sayısı en fazla iki olacak olacak şekilde kullanılan paket program tarafından otomatik olarak belirlenmiştir. Her bir hesaplama adımında iterasyon sayısı maksimum 10 olarak kullanılmıştır. İterasyon adımlarımda akımla ilgili parametrelerin yakınsama kriteri 0,00001 olarak kullanılmıştır. Eğer çözülen parametre bu değere kadar yakınsamış ise 10 iterasyon yapılmadan bir sonraki hesaplama adımına otomatik olarak geçilmiştir. İterasyon sayısının az olması ayrıklaştırma hataların artmasına neden olurken, çok büyük seçilmesi ise sayısal model hesaplama süresinin artmasına neden olmaktadır.

Baraj yıkılma dalgasının hava ile ara kesitinin belirlenmesinde, farklı akım koşullarına sahip problemlerin çözümünde oldukça başarılı olan Akışkan Hacimleri Yöntemi (Volume of Fluids-VOF) kullanılmıştır. Akışkan hacimleri yönteminde, hesaplama ağı elemanın hacimsel doluluk oranını temsilen bir akışkan hacmi $(F)$ tanımlanmaktadır. Hesaplama ağı elemanının su ile tamamen dolu olması durumunda $F=1$ olurken, havayla tamamen dolu olması durumunda ise $F=0$ olmaktadır. Su ile havanın ara kesitinin bulunduğu bölgede ise $F$ değeri sıfır ile bir arasında değişen bir değer almaktadır. Akışkan hacimleri yöntemi ile serbest su yüzünün hesaplanmasında "Geo-Reconstruct" yaklaşımı kullanılmıştır [19].

Sayısal modellemelerde hesaplama ağı tasarımının sayısal modelleme sonuçları üzerinde etkisinin olduğu hesaplamalı akışkanlar dinamiği yöntemine dayalı çözüm yapan araştırmacılar tarafından bilinmektedir [21-24]. Hesaplama ağının sayısal çözümler üzerinde ne kadar etkisinin olduğunun belirlenmesi için üç farklı yoğunlukta hesaplama ağ1 tasarımı yapılmasını zorunluluğu olan A $\breve{g}$ Yakınsama İndeksi (Grid Convergence Index-GCI) oldukça sık kullanılmaktadır [25-28]. Bu çalışmada da üç farklı yoğunluğa sahip hesaplama ağı tasarımı yapılarak ağ yakınsama indeksi kullanılarak, sayısal çözümlerin ağ yapısının etkisinde olmadığ 1 kontrol edilmiştir. GCI analizleri için üç farklı hesaplama ağı tasarımı gerekmekte olup, bu çalışmada tasarlanan hesaplama ağlarına ait görüntüler Şekil 3'te verilmiştir. En büyük ağ elemanlarından oluşan hesaplama ağ $\mathrm{A} \breve{g} 1$, en küçük ağ elemanlarından oluşan hesaplama ağ1 ise Ağ3 olarak adlandırılırken, bu iki ağ elemanına göre orta büyüklükte ağ elemanına sahip hesaplama ağ 1 ise A $\breve{g} 2$ olarak adlandırılmıştır. Bu üç farklı hesaplama ağında A $\breve{g} 1$ 'de 1000x35 adet, A $\breve{g} 2$ 'de $1500 \times 55$ adet ve A $\breve{g} 3$ 'te ise 2000x70 adet dikdörtgen elaman bulunmaktadır. Burada bulunan ilk değer çözüm bölgesinin $x$ boyutunda bulunan eleman sayısını, ikinci eleman ise $y$ doğrultusunda bulunan eleman sayısını göstermektedir. Şekillerden de görüldüğü üzere Ağ3 en sık1 ağ yapısına sahip iken, Ağ1 en kaba ağ yapısına sahiptir. 
$\mathrm{Ag} 1$

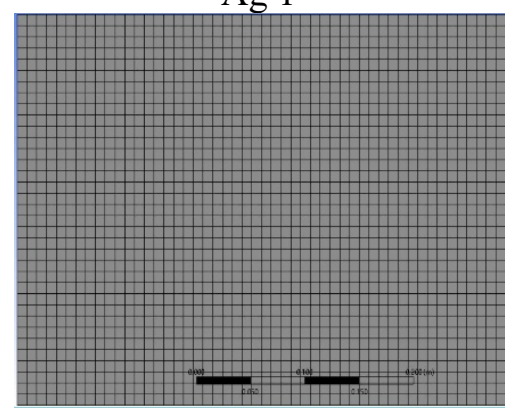

$\mathrm{Ag} 2$

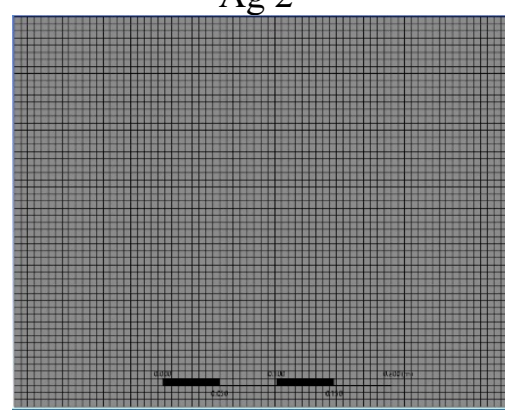

$\operatorname{Ag} 3$

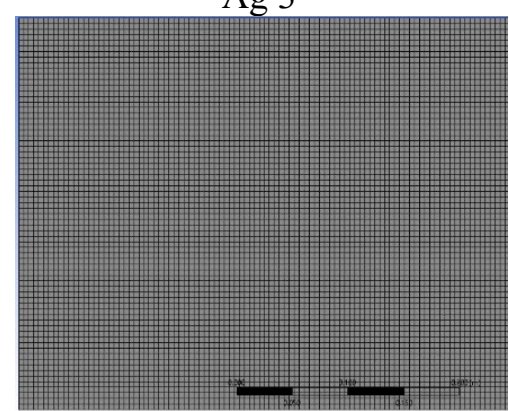

Şekil 3. Farklı yoğunluklu hesaplama ağı tasarımları.

Üç farklı eleman boyutuna sahip hesaplama ağı kullanılarak farklı zaman adımlarında elde edilen sayısal su yüzü profillerinin karşılaştırılması Şekil 4'te verilmiştir. Su yüzü profilinin değişim gösterdiği bölgede oluşan farklı yoğunluktaki hesaplama ağları kullanılarak elde edilen su yüzü profilleri arasındaki farklılıkların belirgin olmasından dolayı bu bölge şekillerde gösterilmiştir. Şekil 4 'te verilen grafikler incelendiğinde, A $\breve{g} 1$ kullanılarak elde edilen su yüzü profillerinin diğer hesaplama ağları kullanılarak elde edilen su yüzü profillerinden düşük seviyede olduğu görülmektedir. Bunun yanında, A $\breve{2}$ ve A $\breve{g} 3$ kullanılarak elde edilen su yüzü profilleri arasında farkın oldukça küçük olduğu açikça söylenebilir. GCI analizi sonucunda elde edilen değerlerden ağ yapısının sayısal sonuçlar üzerindeki etkisinin oldukça kısıtlı olduğu belirlenmiştir. Bu nedenle sayısal modellemelerde Ağ3 hesaplama ağ kullanılmıştır.
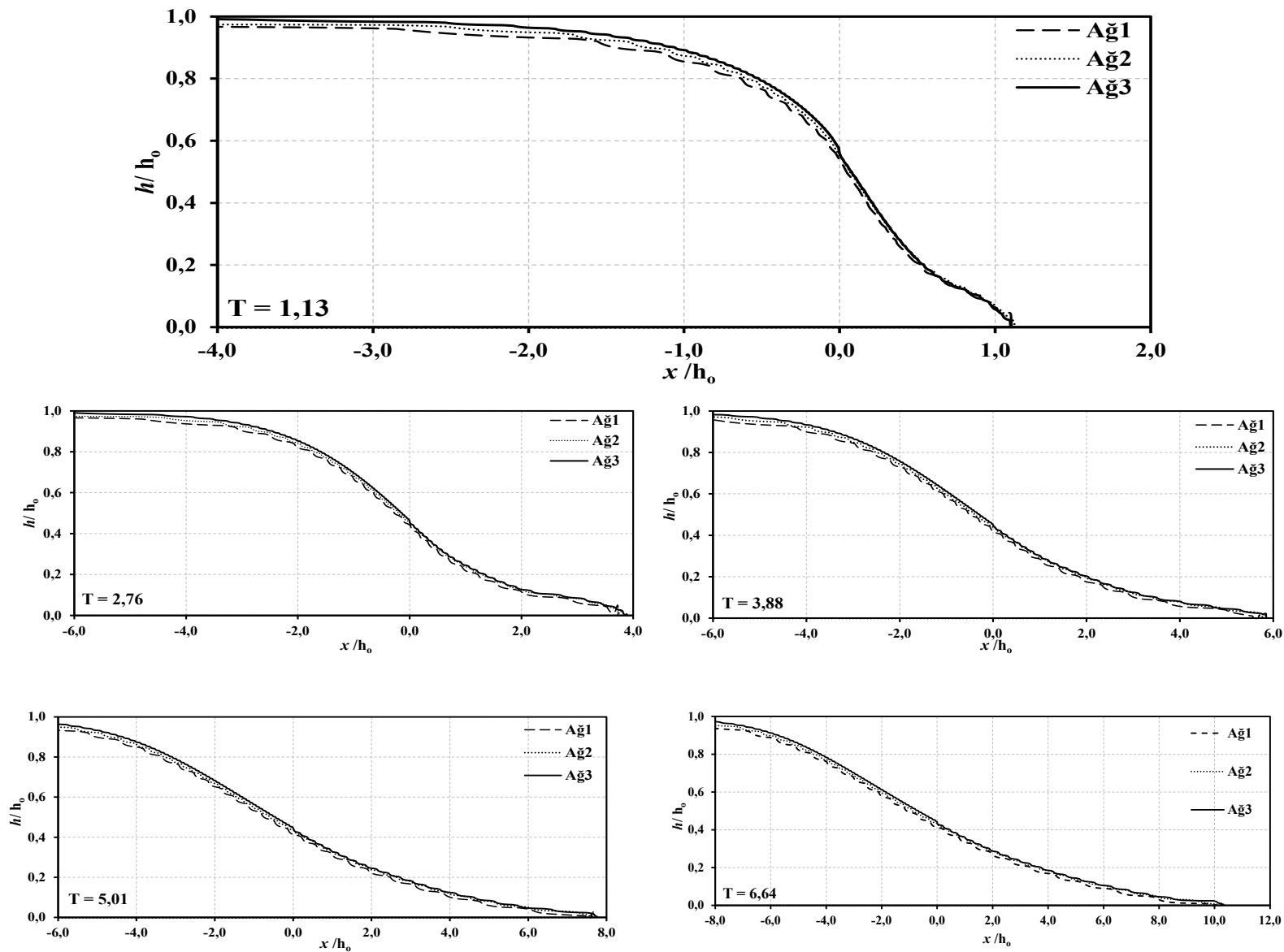

Şekil 4. Farklı eleman boyutlarına sahip hesaplama ağları kullanılarak elde edilen sayısal su yüzü profilleri. 
Sayısal modellemelerde kullanılan sınır ve başlangıç şartları Şekil 5'te verilmiştir. Çözüm bölgesinin giriş sınırında $F=1$ olarak tanımlanarak akımın kanal girişine doğru (negatif yönde) yayılımı engellenmiştir. Çözüm bölgesinin diğer kısımlarında $F=0$ olarak tanımlanmıştır. Çıkış ve üst sınırlarda ise $p=0$ koşulu verilmiş olup, akımın bu bölgeden serbest dökülmesi sağlanmıştır. Kanal alt tabanında ise $u=v=0 \mathrm{~m} / \mathrm{s}$ tanımlanmıştır. Çözüm bölgesinde baraj haznesini temsil etmek üzere ilgili olan su ile doldurulmuş olup baraj yıkılmasının simülasyonu bu şekilde gerçekleştirilmiştir. Deneysel verilerin elde edildiği çözüm sürelerinde sayısal modelleme kayıtları alınarak deneysel ve sayısal verilerin karşılaştırılması yapılmıştır.

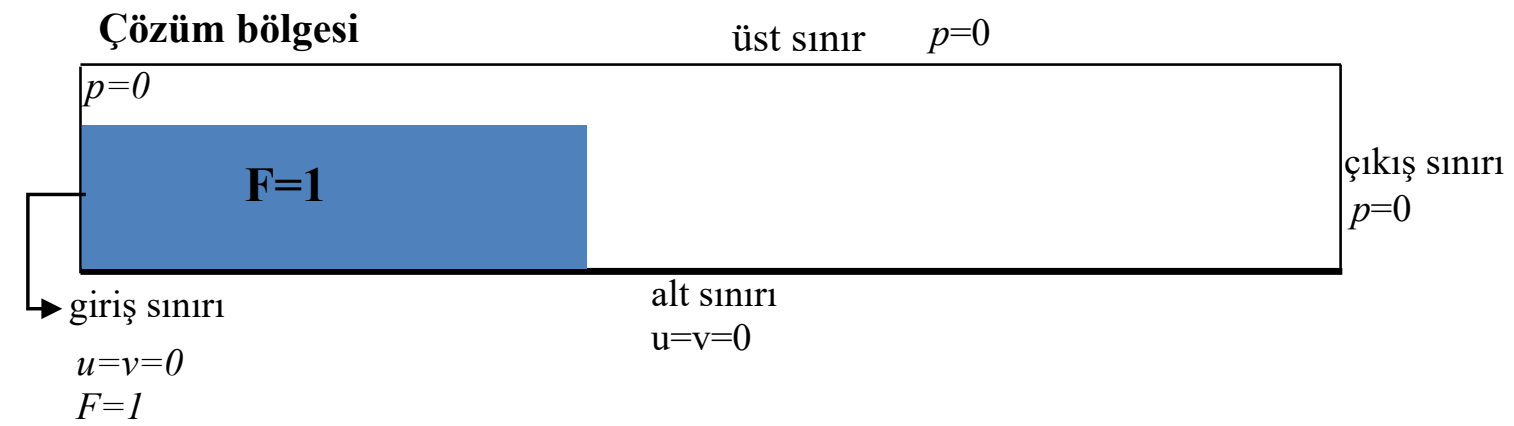

Şekil 5. Çözüm bölgesi, sınır ve başlangıç şartları.

\section{BULGULAR VE TARTISMA}

\section{A. DENEYSEL VE SAYISAL SU YÜZÜ PROFÍLLERİ}

Baraj yıkılması sonucunda oluşan dalganın profilinin belirlenmesi ve herhangi bir noktada oluşan yıkılma dalgasının yüksekliğinin belirlenmesi alınacak önlemlerin belirlenmesinde önem arz etmekte ve yayılım dalgasından korunma yapılarının boyutlarının belirlenmesinde en önemli parametredir. Deneysel ve farklı türbülans modelleri kullanılarak elde edilen sayısal su yüzü profilleri karşılaştırılmıştır. Türbülans modellerinin başarısının belirlenmesinde başarı kriteri olarak Denklem 4 ve 5'te sirasiyla verilen Ortalama Mutlak Göreceli Hata (OMGH) ve Ortalama Karesel Hata $(\mathrm{OKH})$ değerleri kullanılmıştır.

$$
\begin{aligned}
& O M G H=\frac{1}{N} \sum_{n=1}^{N} \frac{\left|h_{d}-h_{s}\right|}{h_{d}} \\
& O K H=\frac{1}{N} \sum_{n=1}^{N}\left(h_{d}-h_{s}\right)^{2}
\end{aligned}
$$

Bu denklemlerde bulunan $h_{d}$ ve $h_{s}$ sırasıyla deneysel ve sayısal su derinliklerini, $\mathrm{N}$ ise ele alınan profildeki nokta sayısını ifade etmektedir. Farklı türbülans modelleri kullanılarak çeşitli zamanlarda elde edilen su yüzü profillerinin deneysel profillerle karşılaştırılması sonucunda elde edilen OMGH ve OKH değerleri Tablo 1'de verilmiştir. Tablo bulunan $\mathrm{OKH}$ ve OMGH değerlerinin parantez içinde verilen üst indisleri kullanılan modellerin başarı sıralamasını göstermektedir. Tüm türbülans modellerinde farklı zamanlarda elde edilen $\mathrm{OKH}$ ve $\mathrm{OMGH}$ değerlerinin ortalaması tablonun son satırında verilmiştir. Tabloda verilen değerler incelendiğinde, $\mathrm{T}=1,13$ için $\mathrm{OKH}$ kriterine göre $\mathrm{RNG}$ modeli deneysel verilere en yakın tahminde bulunurken, OMGH kriterine göre ise bu çözüm adımında DES modeli en yakın tahminde bulunmuştur. $\mathrm{T}=3,88$ için ise $\mathrm{OKH}$ kriterine göre DES modeli, OMGH kriterine göre ise RNG türbülans modeli başarılı olmaktadır. Bu çözüm adımları dışında ele alınan tüm zamanlarda, DES modeli her iki başarı kriterine göre deneysel verilere en yakın su yüzü profilini belirlendiği elde edilen değerlerden görülmektedir. Ayrıca, tablonun son satırında verilen ortalama hata oranları incelendiğinde her iki başarı ölçütüne göre DES modelinin en başarılı olduğu ve türbülans modellerinin başarısı sıralamasının OKH kriterine göre DES, SST ve RNG şeklinde, OMGH kriterine göre ise bu sıralamanın 
DES, RNG ve SST şeklinde oluştuğu anlaşılmıştır. Elde edilen değerlerin karşılaştırılmasından deneysel su yüzü profillerinin sayısal olarak belirlenen profiller arasında ortalama sonuçlara göre \% 10 'dan daha küçük fark bulunduğu ve kullanılan tüm modellerin birbirine oldukça yakın tahminde bulunduğu söylenebilir.

Tablo 1. Farklı türbülans modellerine ait çeşitli zamanlarda elde edilen $\mathrm{OKH}\left(\mathrm{m}^{2}\right)$ ve OMGH (\%) değerleri.

\begin{tabular}{ccccccc}
\hline Model & \multicolumn{2}{c}{ RNG } & \multicolumn{2}{c}{ SST } & \multicolumn{2}{c}{ DES } \\
\hline $\mathbf{T}$ & $\mathbf{O M G H}$ & $\mathbf{O K H}$ & $\mathbf{O M G H}$ & $\mathbf{O K H}$ & $\mathbf{O M G H}$ & OKH \\
\hline $\mathbf{1 , 1 3}$ & $5,69760^{(2)}$ & $0,00056^{(1)}$ & $6,42130^{(3)}$ & $0,00072^{(3)}$ & $5,58780^{(1)}$ & $0,00059^{(2)}$ \\
\hline $\mathbf{2 , 7 6}$ & $7,65670^{(3)}$ & $0,00052^{(3)}$ & $5,83050^{(2)}$ & $0,00047^{(2)}$ & $5,18320^{(1)}$ & $0,00028^{(1)}$ \\
\hline $\mathbf{3 , 8 8}$ & $9,99890^{(1)}$ & $0,00087^{(3)}$ & $10,67420^{(3)}$ & $0,00086^{(2)}$ & $10,11750^{(2)}$ & $0,00058^{(1)}$ \\
\hline $\mathbf{5 , 0 1}$ & $13,85630^{(2)}$ & $0,00140^{(3)}$ & 15,45020 & $0,00130^{(2)}$ & $13,12760^{(1)}$ & $0,00129^{(1)}$ \\
\hline $\mathbf{6 , 6 4}$ & $10,70490^{(3)}$ & $0,00127^{(3)}$ & $9,87500^{(2)}$ & $0,00117^{(2)}$ & $9,15610^{(1)}$ & $0,00093^{(1)}$ \\
\hline Ort. & $9,58288^{(2)}$ & $0,00093^{(3)}$ & $9,65024^{(3)}$ & $0,00090^{(2)}$ & $\mathbf{8 , 6 3 4 4 4 ^ { ( 1 ) }}$ & $\mathbf{0 , 0 0 0 7 3}^{(1)}$ \\
\hline
\end{tabular}

Farklı türbülans modelleri kullanılarak farklı zamanlarda elde edilen su yüzü profillerinin Kocaman [8] tarafından deneysel olarak elde edilen su yüzü profilleriyle karşılaştırılması Şekil 6'da verilmiştir. Verilen şekiller incelendiğinde, $\mathrm{T}=1,13$ için elde edilen sayısal ve deneysel yüzü profilleri arasında kanal tabanına yakın bölgede çok az bir farklılığın bulunduğu görülmektedir. Bu zaman adımı dışında elde edilen su yüzü profillerinin birbiriyle oldukça uyumlu olduğu şekillerden açıkça görülmektedir. Tablo 1'de verilen değerlerden de anlaşıldığı gibi farklı türbülans modelleri kullanılarak elde edilen sayısal su yüzü profilleri arasında çok fazla farklılığın bulunmadığı şekillerden de görülmektedir. Baraj yıkılma dalgası önü dikliğinin azaldığı durumlarda elde edilen deneysel ve sayısal su yüzü profilleri arasındaki uyumun oldukça iyi olduğu görülmektedir.
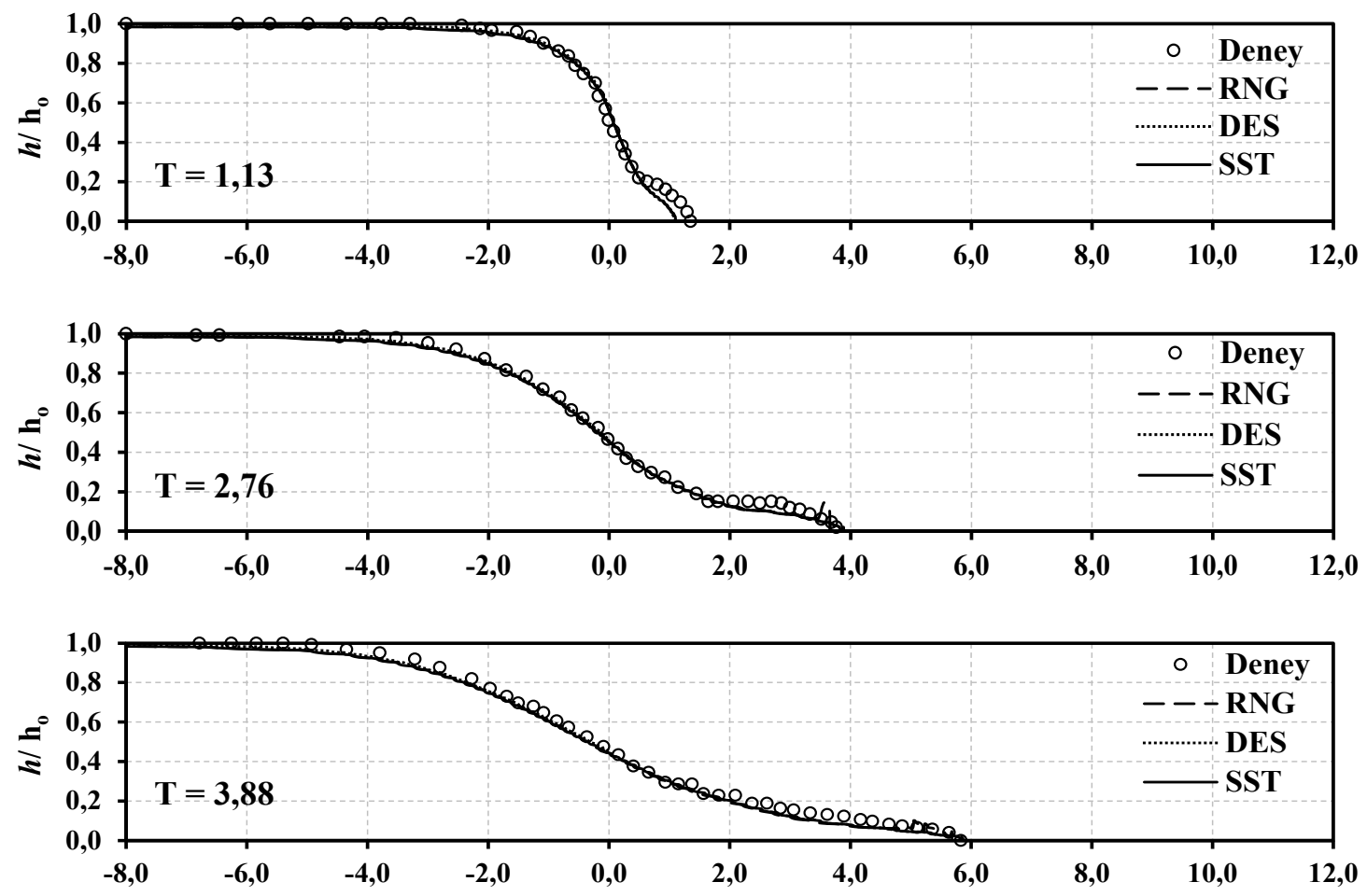

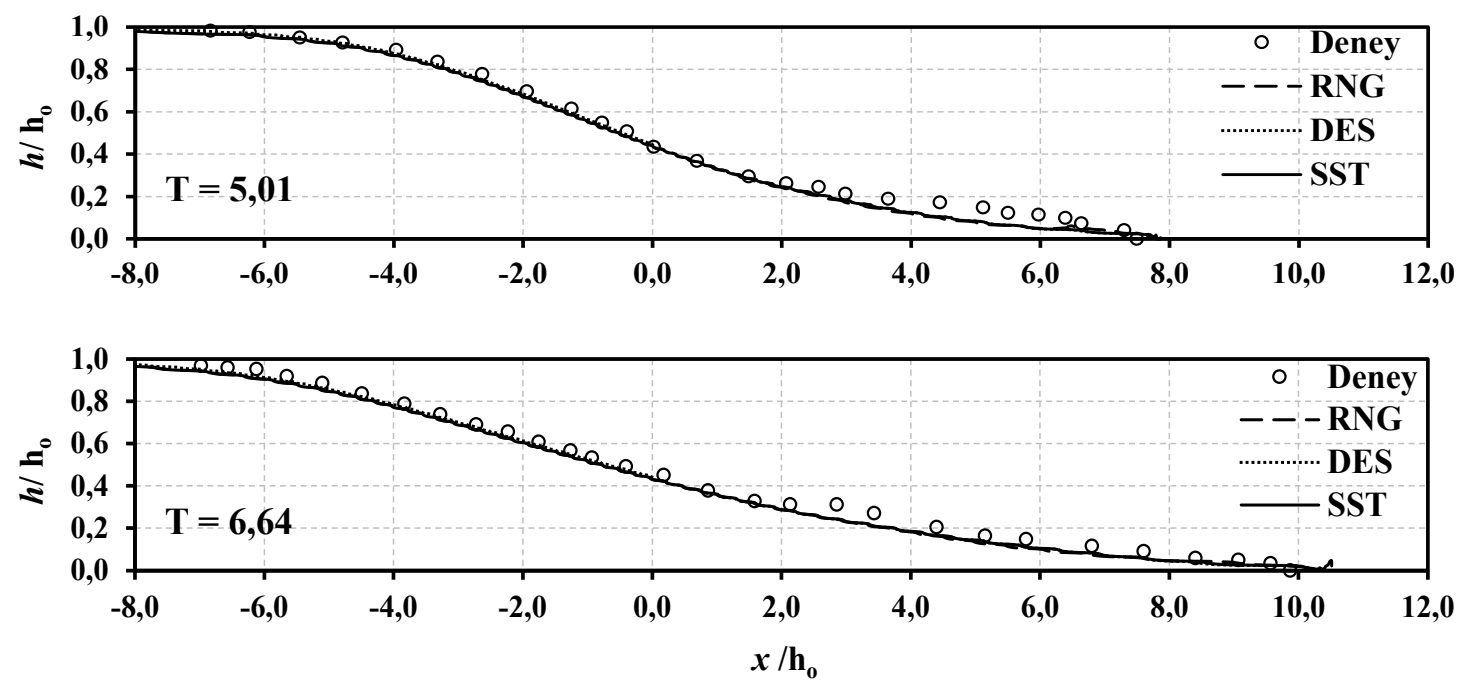

Şekil 6. Deneysel ve farkll türbülans modelleriyle çeşitli zamanlarda elde edilen su yüzü profilleri.

\section{B. SAYISAL HIZ VEKTÖRLERIININ DESENI}

Sayısal ve deneysel su yüzü profillerinin karşılaştırılmasından en başarılı model olan DES modeli kullanılarak farklı zamanlarda elde edilen sayısal hız vektörlerinin desenleri Şekil 7'de verilmiştir. Şekiller incelendiğinde baraj yıkılmasının ilk anlarında elde edilen hız vektörlerinin y doğrultusunda aşağı yönlü oluştuğu görülmektedir. Baraj dalgasının kuru yatak üzerinde ilerlemesiyle y doğrultusunda düşey yönde oluşan hız vektörlerinin $\mathrm{x}$ doğrultusuna doğru değişim gösterdiği ve büyüklüklerinin arttığı söylenebilir. Hesaplama zamanının artmasıyla kuru yatak üzerinde meydana gelen hız vektörlerinin büyüklüğ̈̈nün arttığı belirlenmiştir. Kanal giriş sınırına doğru akımın hareket etmediği elde edilen hız vektörlerinin deseninden görülmektedir.
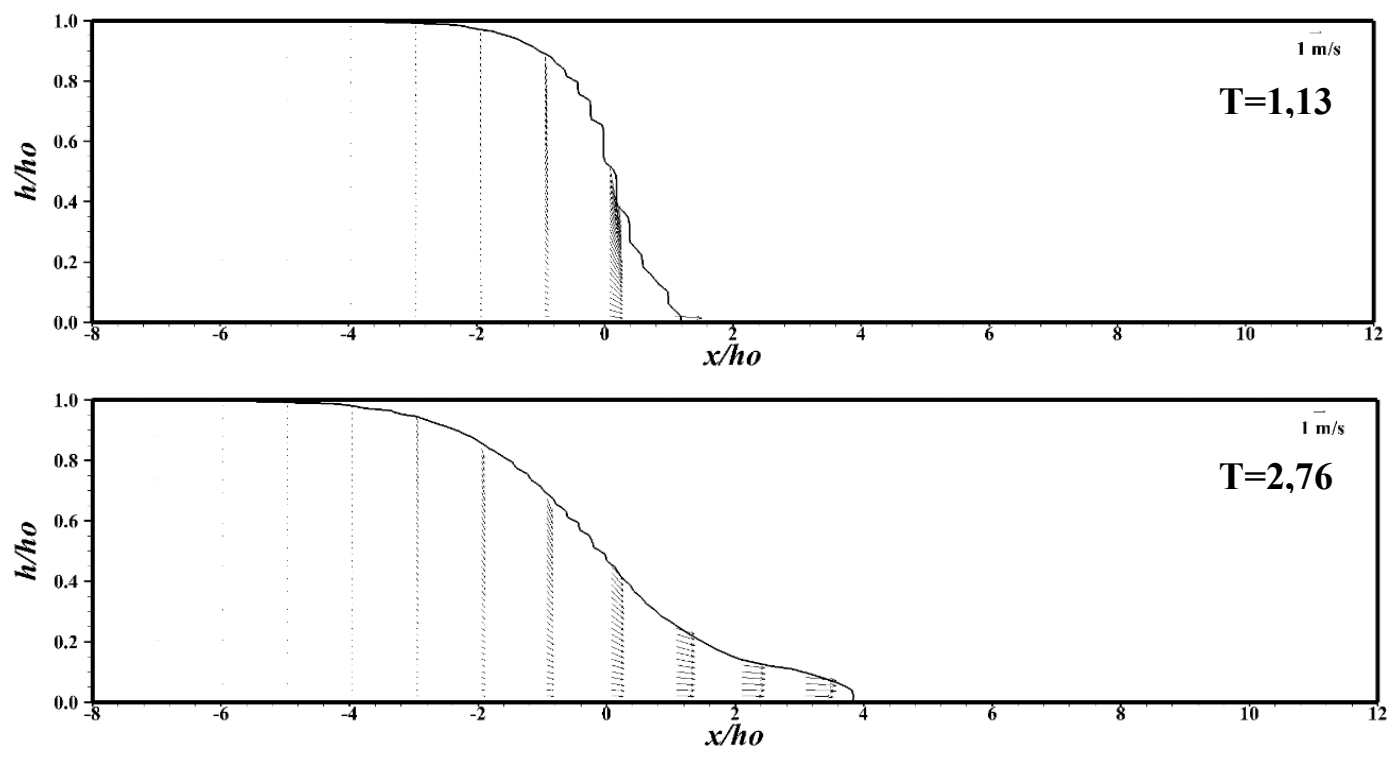

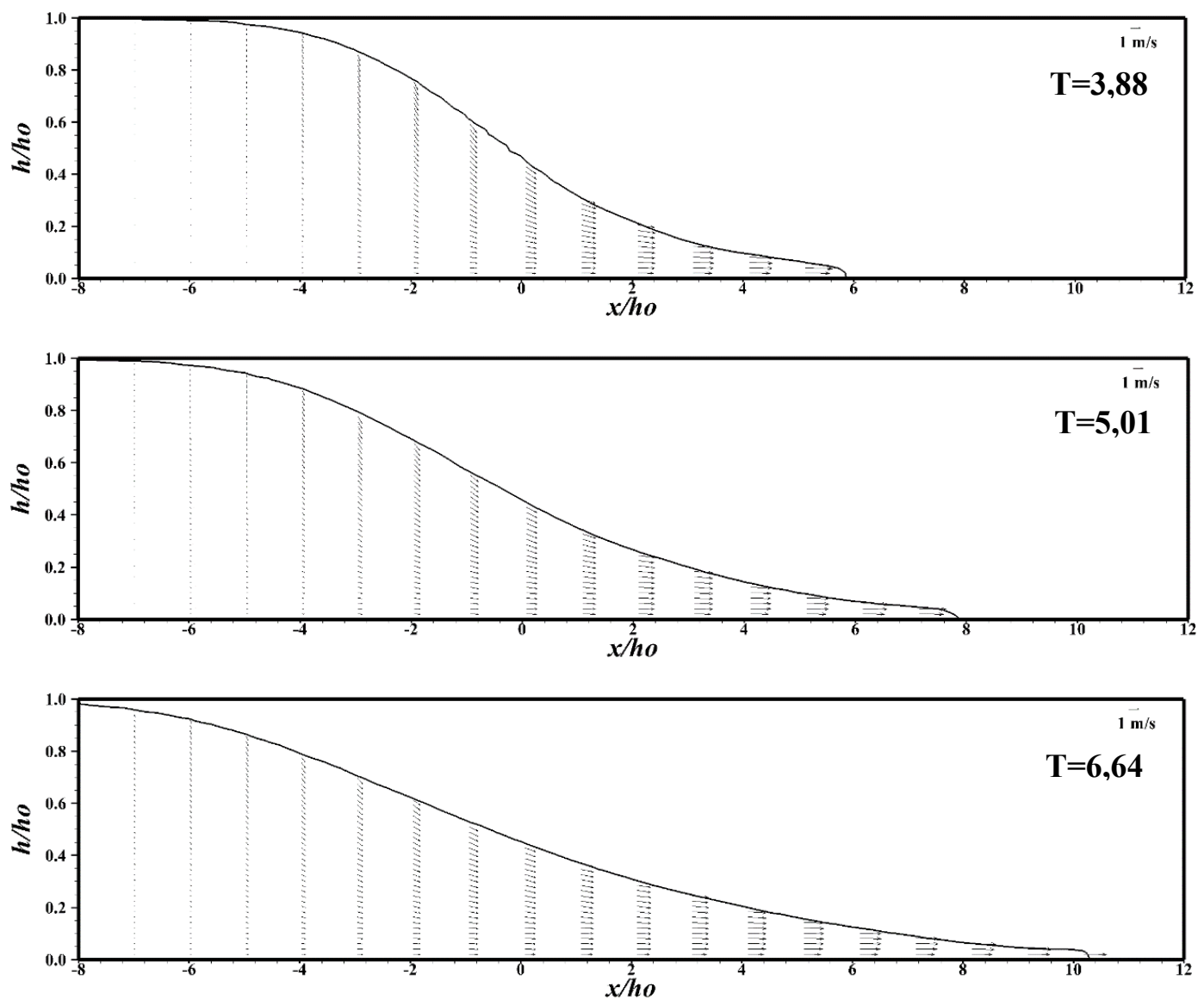

Şekil 7. DES modeliyle farklı zamanlarda elde edilen hız vektörleri deseni.

\section{SAYISAL HIZ DESENI}

Şekil 8'de, en başarılı model olan DES modeli kullanılarak sayısal modelleme sonucunda farklı zamanlarda elde edilen hız değerlerinin desenleri görülmektedir. Farklı çözüm zamanlarında elde edilen hız desenlerinden, baraj yıkılma dalgasının hız alanında $2,2 \mathrm{~m} / \mathrm{s}$ 'den daha büyük hızların yayılım dalgasının önünde oluştuğu görülmektedir. Baraj yıkılma dalgasının kuru yatak üzerinde ilerlemesiyle maksimum hızın oluştuğu bölgenin büyüdüğü açıkça görülmektedir. Bunun yanında, baraj yıkılma dalgasının hız alanında bulunan eğriselliğin yıkılma başlangıcında oldukça belirgin olduğu, yayılım dalgasının yatay yatak üzerinde ilerlemesiyle bu eğriselliğin azaldığı belirlenmiştir. Ayrıca, yayılım dalgasının ele alınan zamanlarda tüm hız alanının harekete geçmediği görülmektedir. Baraj yıkılma dalgasının yatay kuru yatak üzerinde ilerlemesiyle kanal tabanı üzerinde viskoz kuvvetlerin etkisinin arttığı da söylenebilir.

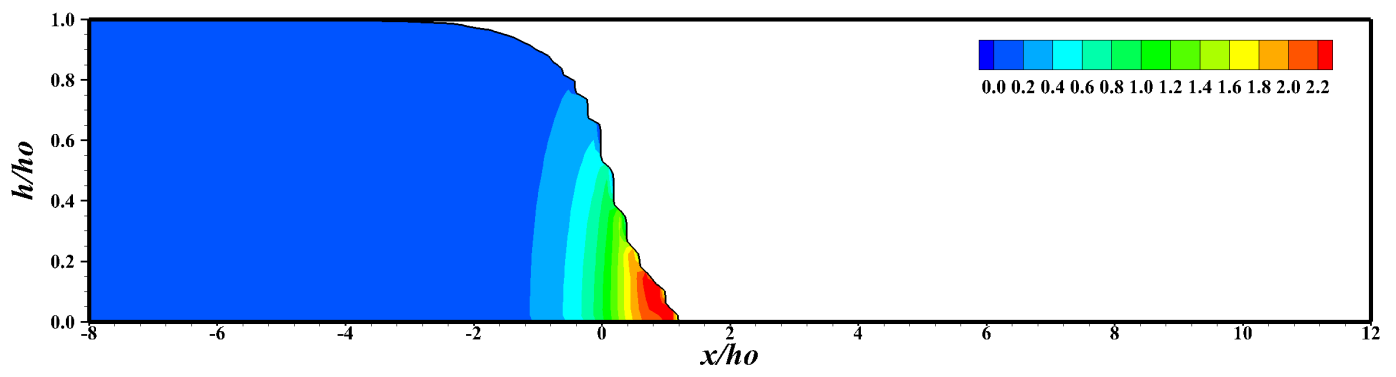



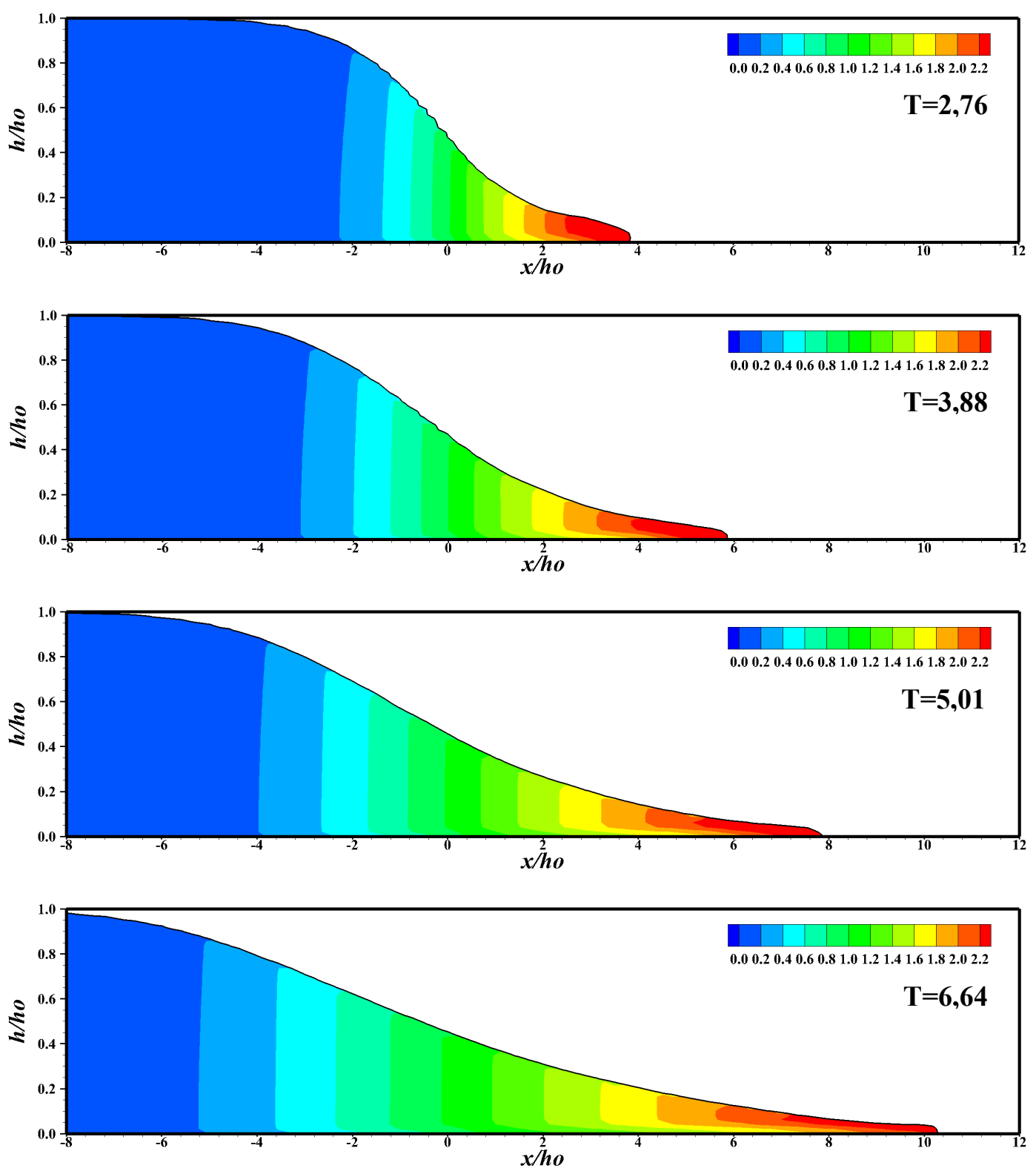

Şekil 8. DES modeliyle farkl zamanlarda elde edilen hız deseni.

\section{SAYISAL TÜRBÜLANS KINETIK ENERJİ DESENİ}

Kuru yatak durumunda meydana gelen baraj yıkılmasını kullanılan diğer modellere kıyasla daha başarılı modelleyen DES modeli kullanılarak elde edilen türbülans kinetik enerjisi desenleri Şekil 9'da verilmiştir. Farklı hesaplama zamanlarında elde edilen türbülans kinetik enerji dağılımlarının incelenmesinden, baraj yıkılması dalgasının uç noktasında hızda meydana gelen değişimin daha fazla olduğu görülürken, zamanın ilerlemesine paralel olarak kuru yatak üzerinde ilerleyen yayılım dalgasının kanal tabanı üzerinde hız değişiminin daha da arttı̆̆ görülmektedir. Baraj yıkılma dalgasının kuru yatak üzerinde ilerlemesiyle birlikte $0,2 \mathrm{~m}^{2} / \mathrm{s}^{2}$ değerinden daha büyük türbülans kinetik enerjisinin oluştuğu görülmektedir. Yayılım dalgasının hareket süresinin artmasıyla, katı sınırla etkileşim bölgesinde elde edilen türbülans kinetik enerjisi değerlerinin arttığı ve alanının büyüdüğü söylenebilir. Hız alanında meydana gelen değişim yayılım dalgasının ön noktasında olduğu görülmektedir. 

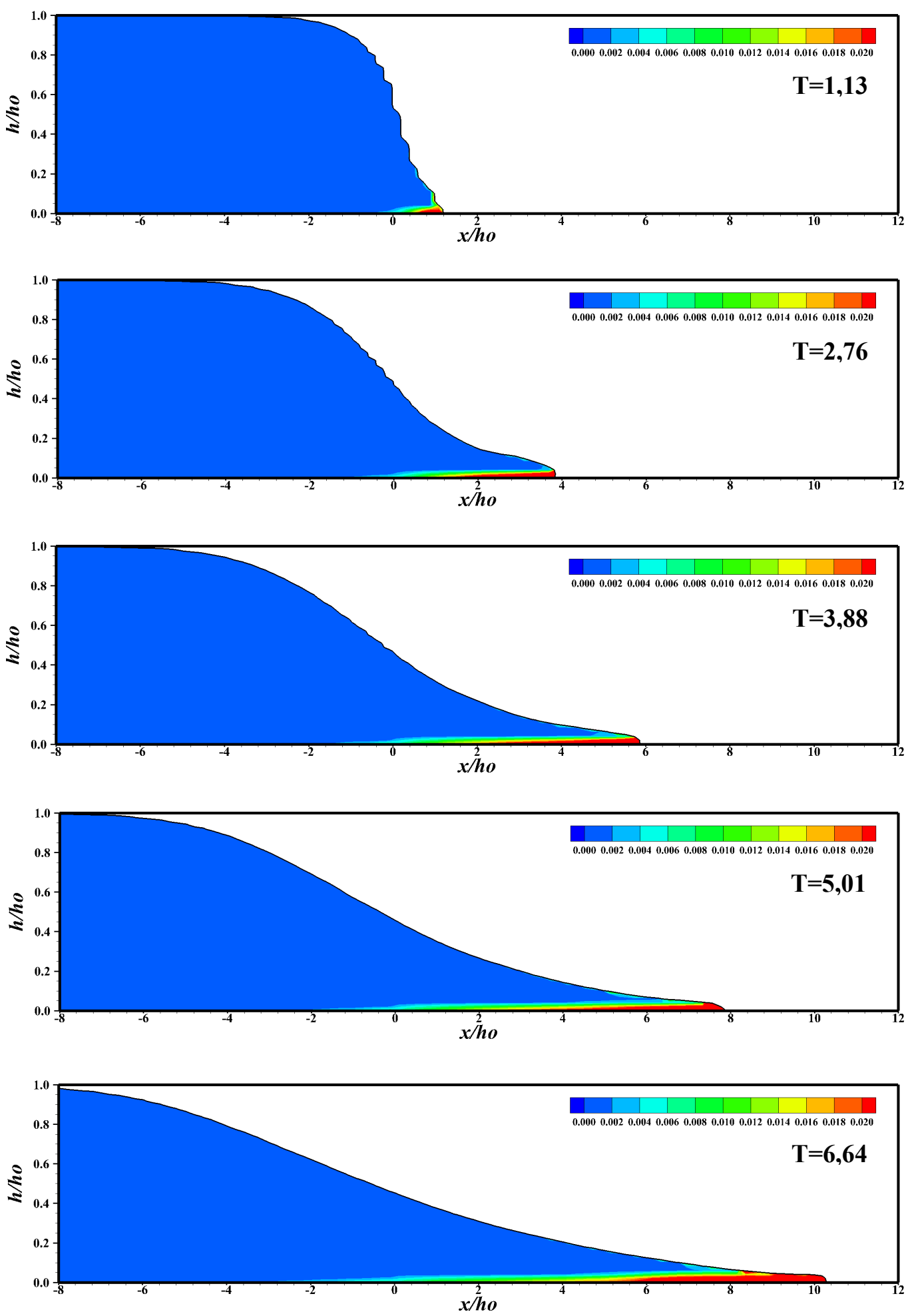

Şekil 9. DES modeliyle farklı zamanlarda elde edilen türbülans kinetik enerji deseni.

\section{V.SONUC}

Baraj yıkılması durumunda oluşan yayılım dalgasının baraj mansabında bulunan yerleşim yerlerinin ve canlıların güvenliğini riske etme düzeyinin belirlenmesi ve erken uyarı sistemlerinin değerlendirilmesi, baraj yapılmadan önce baraj yıkılması modellemesinin sayısal yöntemlerle analiziyle mümkündür. Bu 
çalışmada, kuru yatak üzerinde meydana gelen baraj yıkılması yayılım dalgasının hareketini idare eden temel denklemlerin sayısal modellemesinde, ANSYS Fluent paket programı aracilıyla, RNG, SST ve DES modelleri kullanılmıştır. Baraj yıkılma dalgasının deneysel olarak farklı zamanlarda elde edilen su yüzü profilleri, bu türbülans modelleri kullanılarak elde edilen sayısal su yüzü profilleriyle karşılaştırılmıştır. Türbülans modellerinin farklı zamanlarda elde edilen su yüzü profillerini tahmin etme başarısının belirlemesi için OKH ve OMGH değerleri kullanılmış ve elde edilen sonuçlardan, DES modelinin kullanılan diğer modellere kıyasla nispeten daha iyi tahminde bulunduğu belirlenmiştir. DES modeli kullanılarak elde edilen hız vektörlerinin, hız desenlerinin ve türbülans kinetik enerji dağılımlarının incelenmesinden, baraj yıkılma yayılım dalgasının ön bölgesinde en büyük değerlerin oluştuğu ve yayılım dalgasının kuru yatak üzerinde ilerlemesiyle maksimum değerlerin oluştuğu bölgenin büyüdügü görülmüsşür. Katı sınıra yakın bölgede meydana gelen türbülans kinetik enerjinin, katı sınırdan uzak bölgeye göre daha büyük olduğu belirlenmiş̧ir. Çalışma sonucunda, çalışmada kullanılan türbülans modellerinin baraj yıkılması sonucunda oluşan yayılım dalgasının sayısal modellemesinde başarılı ile kullanılabileceği ve yayılım dalgasının akım karakteristiklerinin farklı akım ve yapı koşulları altında sayısal model sonuçlarından elde edileceği belirlenmiştir. Ayrıca, planlama aşamasında baraj yıkılması modellemesinin ön bilgi edinme açısından detaylı bilgi sunmasından dolayı kullanılabilirliği görülmüştür.

\section{KAYNAKLAR}

[1] M. S. Kirkgoz, M. S. Akoz ve A. A. Oner, "Numerical modeling of flow over a chute spillway,"Journal of Hydraulic Research, vol. 47, no. 6, pp. 790-797, 2009.

[2] H. Ozmen-Cagatay ve S. Kocaman, "Dam-break flow in the presence of obstacle: experiment and CFD simulation,"Engineering Applications of Computational Fluid Mechanics, vol. 5, no. 4, pp. 541-552, 2011.

[3] A. A. Oner, M. S. Akoz, M. S. Kirkgoz ve V. Gumus, "Experimental validation of volume of fluid method for a sluice gate flow," Advances in Mechanical Engineering, vol. 4, pp. 1-10, 2012.

[4] S. Kocaman, "Prediction of backwater profiles due to bridges in a compound channel using CFD," Advances in Mechanical Engineering, c. 6, ss. 1-9, 2014.

[5] V. Gumus, O. Simsek, N. G. Soydan, M. S. Akoz ve M. S. Kirkgoz, "Numerical modeling of submerged hydraulic jump from a sluice gate," Journal of Irrigation and Drainage Engineering, c. 142, s. 1, ss. 1-11, 2016.

[6] O. Simsek, M. S. Akoz ve N. G. Soydan, "Numerical validation of open channel flow over a curvilinear broad-crested weir," Progress in Computational Fluid Dynamics, an International Journal, c. 16, s. 6 , ss. $364-378,2016$.

[7] T. Shigematsu, P. Liu ve K. Oda, "Numerical modeling of the initial stages of dam-break waves," Journal of Hydraulic Research, vol. 142, pp. 183-195, 2004.

[8] S. Kocaman, "Experimental and theoretical investigation of dam-break problem," Doktora tezi, İnşaat Mühendisliği, Fen Bilimleri Enstitüsü, Çukurova Üniversitesi, Adana, Türkiye, 2007.

[9] A. Khoshkonesh, B. Nsom, S. Gohari ve H. Banejad, "A comprehensive study on dam-break flow over dry and wet beds," Ocean Engineering, vol. 188, pp. 1-18, 2019.

[10] D. H. Munoz ve G. Constantinescu, "3-D dam break flow simulations in simplified and complex domains," Advances in Water Resources, vol. 137, pp. 1-16, 2020. 
[11] W. Liu, B. Wang, Y. Guo, J. Zhang ve Y. Chen, "Experimental investigation on the effects of bed slope and tailwater on dam-break flows," Journal of Hydrology, vol. 590, pp. 1-16, 2020.

[12] Y. Ye, T. Xu ve D. Z. Zhu, "Numerical analysis of dam-break waves propagating over dry and wet beds by the mesh-free method," Ocean Engineering, vol. 217, pp. 1-11, 2020.

[13] S. Kocaman, H. Güzel, S. Evangelista, H. Ozmen-Cagatay ve G. Viccione, "Experimental and numerical analysis of a dam-break flow through different contraction geometries of the channel," Water, vol. 12 , no. 4, pp. 1-22, 2020.

[14] L. Peng, T. Zhang, Y. Rong, C. Hu ve P. Feng, "Numerical investigation of the impact of a dambreak induced flood on a structure," Ocean Engineering, c. 223, ss. 1-15, 108669, 2021.

[15] G. Lauber ve W. H. Hager, "Experiments to Dambreak Wave: Sloping Channel," Journal of Hydraulic Research, vol. 36, no. 5, pp.761-773, 1998.

[16] V. Yakhot ve S. A. Orszag, "Renormalization group analysis of turbulence. I. Basic Theory", Journal of Scientific Computing, vol. 1, no.1, pp. 3-51, 1986.

[17] V. Yakhot, S. A. Orszag, S. Thangam, T. B. Gatski ve C. G. Speziale, "Development of turbulence models for shear flows by a double expansion technique," Physics of Fluids a-Fluid Dynamics, vol. 4, no. 7, pp. 1510-1520, 1992.

[18] F. R. Menter, "2-equation eddy-viscosity turbulence models for engineering applications," AIAA Journal, vol. 32, no. 8, pp. 1598-1605, 1994.

[19] ANSYS, Fluent Theory Guide, ANSYS Inc. USA, 2018.

[20] M. S. Aköz, N. G. Soydan, ve O. Şimşek, "Kritik üstü açik kanal akiminin detached eddy ve large eddy simülasyon ile sayısal modellenmesi," Gazi Üniversitesi Fen Bilimleri Dergisi Part C: Tasartm ve Teknoloji, c. 4, s. 4, ss. 213-224, 2016.

[21] T. Avudaiappan, V. Vijayan, S. S. Pandiyan, M. Saravanan ve S. Dinesh, "Potential flow simulation through lagrangian interpolation meshless method coding," Journal of Applied Fluid Mechanics, vol.11, pp. 129-134, 2018.

[22] N. G. Soydan, O. Şimşek ve M. S. Aköz, "Prediction and validation of turbulent flow around a cylindrical weir," European Water, vol. 57, pp. 85-92, 2017.

[23] R. Dutta ve T. Xing, "Quantitative solution verification of large eddy simulation of channel flow," In Proceedings of the 2nd Thermal and Fluid Engineering Conference and 4th International Workshop on Heat Transfer, Las Vegas, 2017, April.

[24] M. S. Kirkgoz, M. S. Akoz ve A. A. Oner, "Experimental and theoretical analyses of twodimensional flows upstream of broad-crested weirs," Canadian Journal of Civil Engineering, vol.35 no. 9, pp. 975-986, 2008.

[25] O. Şimşek, N. G. Soydan, V. Gümüş, M. S., Aköz ve M. S. Kırkgöz, "Numerical modeling of B-Type hydraulic jump at an abrupt drop," Teknik Dergi, vol. 26, no. 4, pp. 7215-7240, 2015.

[26] P. J. Roache, "Perspective: a method for uniform reporting of grid refinement studies," Journal of Fluids Engineering -Transactions of the ASME, c. 116, s. 3, ss. 405-413, 1994. 
[27] L. Eça ve M. Hoekstra, "A procedure for the estimation of the numerical uncertainty of CFD calculations based on grid refinement studies," Journal of Computational Physics, vol. 262, pp. 104130,2014

[28] A. Mansour ve E. Laurien, "Numerical error analysis for three-dimensional CFD simulations in the two-room model containment THAI+: Grid convergence index, wall treatment error and scalability tests," Nuclear Engineering and Design, vol. 326, pp. 220-233, 2018. 